Paulina Nicko-Stępień

Papieski Wydział Teologiczny

Wrocław

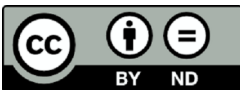

\title{
Wulgata Lowańska a Nowy Testament w przekładzie ks. Jakuba Wujka z roku 1593 Studium Mt 16, 13-20
}

Artykuł jest poświęcony wpływowi Wulgaty Lowańskiej na warsztat Jakuba Wujka - jednego z najbardziej znanych tłumaczy biblijnych XVI w. Zależność ta została ukazana na przykładzie perykopy o obietnicy prymatu św. Piotra z Mt 16, 13-20. Do tej pory w badaniach nad metodą tego jezuity z Wągrowca posługiwano się przypadkowymi wydaniami Wulgaty (różnymi od tych, z których tłumacz korzystał, a nawet współczesnymi), co prowadziło do błędnych wniosków na temat jego warsztatu. Niniejszy artykuł zawiera dokładnie te edycje, na których Wujek opierał swoją pracę. To doprowadziło do odkrycia, że noty marginalne umieszczane przez tłumacza przy tekstach nie były sporządzane przez niego, ale przepisywane z Wulgaty Lowańskiej.

Słow a klu czow e: Jakub Wujek, tłumaczenia Biblii, Wulgata Lowańska, reformacja, prymat św. Piotra, Ewangelia według św. Mateusza

Keyw ords: Jakub Wujek, Bible translations, Louvain edition of the Vulgate, Protestant Reformation, primacy of St Peter, Gospel according to Matthew

Ksiądz Jakub Wujek SJ (1541-1597) uważany jest za jednego z najwybitniejszych tłumaczy biblijnych okresu kontrreformacji. Dobrze opanował teologię, filozofię oraz filologię biblijną. Rozumiał siłę i znaczenie słowa drukowanego w językach narodowych oraz wagę lektury Pisma Świętego - księgi stanowiącej centrum zainteresowań nie tylko 
najwybitniejszych umysłów epoki, ale także osób posiadających przynajmniej podstawowe wykształcenie.

W ciągu ostatnich lat ukazały się znaczące opracowania naukowe poświęcone osobie Jakuba Wujka i jego przekładom. Wśród najważniejszych można wymienić reprint Biblii Wujka z 1599 r. wydany wraz z opracowaniem w serii Biblia Slavica ${ }^{1}$. Wśród polskich znawców Jakuba Wujka trzeba wspomnieć następujących badaczy²: Danutę Bieńkowską ${ }^{3}$, Joannę Sobczykową ${ }^{4}$, Marię Kossowską ${ }^{5}$, Hugolina Langkammera $^{6}$, Janinę Czerniatowicz ${ }^{7}$ i Dariusza Kuźminęe .

Prowadząc badania nad Wujkowym przekładem Biblii i nad warsztatem translatorskim jezuity z Wagrowca, do tej pory zazwyczaj posługiwano się dowolnie wybranymi tekstami biblijnymi (greckimi, łacińskimi i hebrajskimi), przyjmując je za podstawę analiz porównawczych. Tak uczyniła M. Kossowska, zupełnie ignorując w swych badaniach Wulgatę Lowańską, która była przecież podstawą przekładu Wujka. Autorka, pomijając ten jeden z najważniejszych tekstów używany przez Wujka w praktyce translatorskiej, bardzo nieprecyzyjnie

${ }^{1}$ Biblia to iest Ksiegi Starego y Nowego Testamentu wedtug Eacińskiego przektadu starego, w kośćiele powszechnym przyiętego, na Polski ięzyk z nowu z pilnoścía przetożone. $Z$ doktadaniem textu Żydowskiego y Greckiego, y z wyktadem Katholickim, trudnieyszych mieysc, do obrony Wiary świętej i powszechney przeciw kacerztwom tych czasów należacych. Przez D. Jakuba Wuyka z Wagrowca Theologa Societatis Iesu. W Krakowie, Roku Pańskiego M.D.XCIX, red. I. Kwilecka, H. Rothe, Padeborn-München-Wien 2010, Ferdinand Schöningh, Biblia Slavica. Polnische Bibeln V/1-2.

2 Badacze wymienieni według dyscyplin naukowych: badania nad historią książki, badania nad Biblią, badania filologiczne, badania z zakresu bibliologii i informacji naukowej.

${ }^{3}$ D. Bieńkowska, Jak Jakub Wujek Pismo Święte na język polski przektadat (O warsztacie ttumacza i technice przez niego stosowanej), „Bobolanum”, IX, 1998, s. 27-52; eadem, Rola glos marginalnych w przektadzie Biblii J. Wujka, „Acta Universitatis Lodziensis. Folia Linguistica”, XXIII, 1990, s. 21-29; eadem, Styl językowy przektadu Nowego Testamentu Jakuba Wujka (na materiale czterech Ewangelii), Łódź 1992, Wydawnictwo UŁ.

${ }^{4}$ J. Sobczykowa, Myśl o języku w komentarzu biblijnym ks. Jakuba Wujka, Katowice 2001, Wydawnictwo UŚ.

${ }^{5}$ M. Kossowska, Biblia w języku polskim, t. 1, Poznań 1968, Księgarnia św. Wojciecha, s. 313-360.

${ }^{6}$ H. Langkammer, Przektad Biblii Wujka na tle zmagań $i$ potrzeb religijno-teologicznych ówczesnego Kościota w Polsce, „Bobolanum”, IX, 1998, s. 53-63.

7 J. Czerniatowicz, Niektóre problemy naukowe grecystyki w pracach biblistów polskich XVI i XVII wieku. Teksty greckie a polskie przektady, Wrocław 1969, PAN, Monografie w Dziejów Nauki i Techniki, t. 53, s. 70-84.

8 D. Kuźmina, Jakub Wujek (1541-1597). Pisarz, ttumacz i misjonarz, Warszawa 2004, Stowarzyszenie Bibliotekarzy Polskich. 
zaprezentowała metodę jego pracy. Założyła bowiem, że Wujek sam konfrontował różne wersje, dokonując krytyki tekstu ${ }^{9}$. Analogicznie postąpiła D. Bieńkowska ${ }^{10}$. W ten sposób ignorowano zazwyczaj fakt, że szesnastowieczne teksty łacińskie i greckie Biblii nie były identyczne z dzisiejszymi oraz że w XVI w. teksty biblijne łacińskie (Wulgata), greckie (Septuaginta) oraz hebrajskie różniły się między sobą w zależności od wydania. Nie chodzi tu oczywiście o różnice zmieniające prawdy wiary, ale o drobne warianty znajdujące odbicie w przekładzie (np. zmiana szyku wyrazów, obecność lub brak pojedynczych słów, rzadziej wersetów itd.). Zdarzało się nawet, że do badań nad tłumaczeniem Wujka używano współczesnych wydań Wulgaty czy greckiego Nowego Testamentu ${ }^{11}$. J. Sobczykowa w bibliografii do swoich rozpraw zamieściła tylko dwudziestowieczne wydania Wulgaty i Septuaginty, podobnie D. Bieńkowska i M. Kossowska ${ }^{12}$. Najbardziej precyzyjne badania przeprowadziła J. Czerniatowicz, skorzystała ona bowiem z szesnastowiecznych wydań Biblii, pochodzących jednak z lat dziewięćdziesiątych, a więc także nie tych, na których swoje prace opierał Wujek ${ }^{13}$. Tłumacz wyraźnie napisał, z jakich edycji korzystał: „Łacińskiego zasię egzemplarza onegom się trzymał, który od lowańskich teologów pilnie jest przejrzany, poprawiony i z oryginałami greckimi, asyryjskimi i z łacińskimi starymi pisanymi księgami zniesiony, który tenże Plantinus w Antorfie drukował in Roku Pańskiego 1574" ${ }^{14}$.

${ }^{9}$ M. Kossowska, op. cit., s. 322-326. Autorka zakładała, że Wujek sam sporządzał noty marginalne.

${ }^{10}$ D. Bieńkowska, Rola glos, s. 22. Autorka pisze, że część not marginalnych związanych jest z odwołaniem się Wujka do różnych greckich i łacińskich tekstów Pisma Swiętego. Być może przyjęła założenie, że tłumacz sam sporządzał noty dotyczące krytyki tekstu.

${ }^{11}$ Eadem, Jak Jakub Wujek, s. 39. Autorka wyraźnie zaznacza, że odnosi się do wydania Wulgaty z roku 1975. Por. L. Moszyński, Stworzenie świata (Gn 1,1-31) w przektadzie Wujka z Wulgaty (1599) i Budnego z hebrajskiego (1572), [w:] Jan Jakub Wujek. Ttumacz Biblii na język polski. W czterechsetna rocznice wydania Nowego Testamentu 1593-1993. Księga referatów wygtoszonych na konferencji 26 kwietnia 1993, Łódź 1994, Archidiecezjalne Wydawnictwo Łódzkie, s. 50-58. Autor także powołuje się na stuttgarckie wydanie Wulgaty z roku 1975.

${ }^{12}$ Z 1983 i 1979 r. Zob. J. Sobczykowa, op. cit., s. 247. D. Bieńkowska odniosła się wielokrotnie do Wulgaty z lat osiemdziesiątych XX w., M. Kossowska sięgnęła natomiast do Wulgaty Klementyńskiej (wydanej w Rzymie w 1956 r.).

13 J. Czerniatowicz, op. cit., s. 127.

14 J. Wujek, Przedmowa do czytelnika, [w:] Nowy Testament w przektadzie ks. dr Jakuba Wuika T.J. z roku 1593, red. W. Smereka, Kraków 1966, Polskie Towarzystwo Teologiczne, s. LXVIII. 
Podobnych przykładów zastosowania współczesnych tekstów biblijnych do badań nad Wujkowym tłumaczeniem wymienić można dużo więcej ${ }^{15}$. Czy jednak taka metoda badawcza nie jest błędem metodologicznym? Czy posługując się przy porównywaniu tekstów Wujkowych przekładów oryginalnymi edycjami z XVI w., tymi samymi, z których korzystał Wujek, nie dojdzie się do wyników nieco innych niż dotychczas? Czy sięgnięcie po oryginalne edycje zmieni nasze spojrzenie na warsztat i metodę pracy biblisty z Wagrowca? Celem niniejszego artykułu jest prezentacja wyników badań nad perykopą Mt 16, 13-20 w oparciu o znane Wujkowi edycje Biblii.

Jakub Wujek i jego warsztat

Wujek, przystępując do prac translatorskich, zdecydował się oprzeć głównie na tekście zwanym editionem vulgatam, respektując jego autorytet zatwierdzony przez Kościół katolicki, głównie na soborze trydenckim (1545-1563), który - jak pisał Wujek - chwali tekst łaciński „i za pewny mieć każe”" Kolejną przyczyną, dla której wybrał wersję Hieronimową, było mniejsze, jego zdaniem, zniekształcenie tekstu łacińskiego niż greckiego. Czytamy bowiem w Przedmowie, że łacinnicy mieli tylko jedną sektę homouzyjańską, a przy tym nie posiadali zbyt światłych umysłów, więc siłą rzeczy wyrządzili mniej szkód swoimi przekładami ${ }^{17}$. Wujek korzystał z edycji lowańskiej, wydanej w 1574 r. w Antwerpii. Będąc teologiem i egzegetą, nie poprzestał jednak na tekście Hieronima, ale odwołał się także do oryginału greckiego i, w przypadku Starego Testamentu, do hebrajskiego, by czytelnikowi dać możliwość polemiki z wersjami innowierczymi i tym samym ograniczyć nadużycia w interpretacji.

Dokonując przekładu Biblii, Wujek uważał, aby nie popełniać błędów wypaczających pierwotny sens Pisma Świętego. Jako spadkobierca najszlachetniejszej tradycji in arte translatoria, zobligowany przez Kościół do zachowania wierności Wulgacie, w swoich pracach kierował się trzema zasadami św. Hieronima: zrozumienia sensu,

${ }^{15}$ Np. E. Siatkowska, Samodzielność przektadu Nowego Testamentu przez Jakuba Wujka, Jana Blahoslava i Michata Frencla, [w:] Biblia a kultura Europy. 2000 lat chrześcijaństwa, t. 1, red. M. Kamińska, E. Małek, Łódź 1992, Wydawnictwo UŁ, s. 73-80; D. Bieńkowska, Jakub Wujek - nowator czy tradycjonalista?, [w:] ibidem, s. 143-146; E. Bereza, Odmiana nazw wtasnych w Nowym Testamencie Biblii Wujka i Biblii Tysiaclecia, [w:] ibidem, s. 153.

${ }^{16} \mathrm{~J}$. Wujek, op. cit., s. LVII.

17 Zob. ibidem, s. LIX. 
zrozumienia tekstu oraz zachowania elegancji i walorów artystycznych. Co więcej, starał się oddać stare wyrażenia i dawną terminologię religijną, rezygnując $\mathrm{z}$ tworzenia neologizmów i terminów nieznanych chrześcijanom. Opierając się na przeświadczeniu, że literalność przekładu niekoniecznie sprzyja jego klarowności, ze wszystkich powyższych zasad uczynił Wujek zasadę „złotego środka”, by językowo pozostać wiernym Wulgacie (i w pewnej mierze wersjom oryginalnym), ale jednocześnie, by zatroszczyć się także o przejrzystość polskiego tekstu ${ }^{18}$. To, co wyróżniało jego tłumaczenia, a jednocześnie pozwalało trafnie oddać sens zależnie od kontekstu i zrozumieć słowo, to ogromna liczba językowych dodatków napisanych kursywą oraz rozbudowujących tekst. Wprowadzone zwroty i wyrażenia bez odpowiedników w językach oryginalnych miały zwiększyć spójność tekstu, jak również jego dynamikę.

Edycje stanowiące podstawę przekładu Nowego Testamentu z 1593 r. $^{19}$

Tłumacząc Nowy Testament, Wujek opierał się na dwóch wydaniach Biblii. Były to: Wulgata Lowańska ${ }^{20}$ i Poliglota Antwerpska. Wulgata to przekład Biblii z języka greckiego, hebrajskiego i aramejskiego na język łaciński, dokonany przez św. Hieronima (ok. 345-420). W renesansie ukazało się wiele różniących się od siebie edycji tekstu, w tym właśnie Wulgata Lowańska. Prace nad nią rozpoczęły się pod kierunkiem Jana Hentena (1499-1566) w 1546 r., kiedy to, po porównaniach najlepszych wydań Biblii i trzydziestu manuskryptów, rok później u Bartłomieja Gradiusa w Lowanium wydano przekład Pisma Świętego pod tytułem Biblia sacra ad vetustissima exemplaria castigata. Potem kontynuowano prace, posiłkując się tym razem siedemdziesięcioma manuskryptami, a rezultatem były edycje Wulgaty Lowańskiej

18 S. Sawicki, Biblia Wujka w kulturze polskiej, „Studia Gnieźnieńskie”, I, 1975, s. 315-320.

${ }^{19}$ Nowy Testament Pana naszego IESVSA CHRISTVSA. Z nowu z Laćińskiego y z Gręckiego na Polskie wiernie a szczyrze przetożony: y Argumentami abo Summariuszami każdych Kśiag / y Rozdźiatow / y Annotacyami po brzegach obiaśniony. Przydane sa Nauki y Przestrogi mato nie za każdym Rozdźiatem: Porownanie Ewangelistow SS. Dźieie y drogi rozmaite Piotra y Pawta S. y Regestr rzeczy gtownieyszych na końcu. Przez D. IAKVBA WVYKA, Theologa Societatis IESV. Z dozwoleniem Starszych. Pod rozsądek Kościota S. Powszechnego Rzymskiego wszytko niech podlęże, Kraków 1593 (egz. BO, sygn. XVI.Qu.3065).

20 Biblia sacra: Quid in hac ediotione a Theologis Louaniensibus praesitum sit, paolo post indicatur, Antverpiae, K. Plantinus, 1574, $8^{\circ}$, egz. BK I $24 . O$. 
drukowane w Antwerpii u Christophe'a Plantina w 1565 i 1569 r., a następnie przedrukowywane jeszcze, $\mathrm{m}$.in. w Wenecji u Lucantonia Giunty (1457-1538) w latach 1571 i 1572. Dwa lata później Benois Arias Montanus (1527-1598) - redaktor wersji określanej jako Poliglota Antwerpska - poprawił jeszcze raz poprzednie edycje i opublikował nową Wulgatę, wydaną także u Plantina w roku 1574. Uzyskała ona w Kościele katolickim status textus receptus, którym cieszyła się do czasu upublicznienia Wulgaty Sykstyńskiej $(1590)^{21}$. Tej właśnie edycji z 1574 r. używał Jakub Wujek.

Poliglota Antwerpska (1572) ${ }^{22}$ była wielojęzycznym wydaniem Biblii, ze szczególnym uwzględnieniem przekazów łacińskich, greckich oraz syryjskiej Peszitty (dla Nowego Testamentu). Takie zestawienie oryginalnego tekstu z tłumaczeniem służyło przede wszystkim krytyce tekstu. Poliglota została wydrukowana w Antwerpii w 1572 r. u Plantina pod kierownictwem Benois Ariasa Montanusa, na zamówienie króla Hiszpanii Filipa II, stąd inna nazwa: Biblia Regia lub Plantiniana ${ }^{23}$.

Studium porównawcze różnych wersji tekstu $\mathrm{Mt} 16,13-20$

W celu ustalenia metody pracy translatorskiej Wujka porównamy ze sobą jego tłumaczenie oraz teksty, które stanowiły podstawę ich przekładu. W tym celu posłużymy się fragmentem z Mt 16, 13-20 (obietnica prymatu). Zestawimy obok siebie wersję Wujka z 1593 r. (dalej jako: NTW), Wulgatę Lowańską (dalej jako: WL) oraz wersje: syryjską (PAnS), łacińską (PAnV) i grecką (PAnG) z Poligloty Antwerpskiej.

Werset 13:

NTW 1593: $f$ A gdy przyszedł Jezus w strony Cezarejej Filipowej, pytał uczniów swoich mówiąc: $g$ Czym * mienią być ludzie Syna Człowieczego?

${ }^{21}$ R. Pietkiewicz, W poszukiwaniu „szczyrego” Stowa Bożego. Recepcja zachodnioeuropejskiej hebraistyki w studiach chrześcijańskich w Rzeczypospolitej dobry renesansu, Wrocław 2011, Rozprawy naukowe PWT, t. 86, s. 89-90. Por. też G. Voste, La volgata al Concilio di Trento, „Biblica”, XXVII, 1946, s. 301-319.

22 Biblia Sacra Hebraice, Chaldaice, Graece et Latine. Philippi II Reg. Cathol. Pietate Et Studio Ad Sacrosanctae Ecclesiae Usum, t. 1-8, Antverpiae 1569-1572 (egz. Biblioteka Uniwersytecka we Wrocławiu, sygn. 464835).

23 Zob. Biblia Polyglotta, [w:] Encyklopedia wiedzy o ksiażce, red. A. Birkenmajer, B. Kocowski, J. Trzynadlowski, Wrocław 1971, Ossolineum, s. 146-148. 
* mnie z L. K. G. S. ale Hieronim tego słówka nie czytał $^{24}$.

$f \mathrm{Mk} 8,27^{25}$

$g$ Łk 9,18

WL: $\quad \|$ Venit autem Iesus in partes Caesareae Philippi: $\&$ interrogabat discipulos suos, dicens, \| Quem * dicunt homines esse filium hominis?

Mk 8, 27

Łk 9, 18

* me 3.

MS. R. G. S. at Hier.

PAnS: Quum autem venisset Jeschua in regionem Caesareae Philippi, interrogavit discipulos suos, inquiens, Quid dicunt de me homines, me esse filium hominis?

PAnV: Venit autem Iesus in partes Caesareae Philippi: $\&$ interrogabat discipulos suos, dicens, Quem me dicunt homines esse, filium hominis?

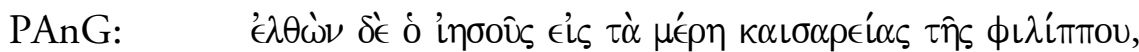

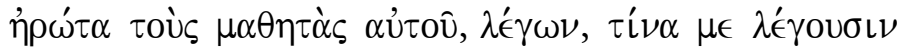

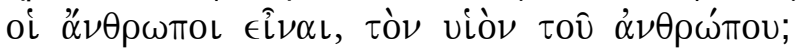

Mk 8, 27

Łk 9, 18

Analiza porównawcza wersetu pokazuje, że Wujek korzystał z WL, o czym świadczą m.in. te same odsyłacze do miejsc paralelnych i uwagi krytyczno-tekstualne. Jednak nie trzymał się niewolniczo jej tekstu, dodając do swojego tłumaczenia słowa, których w wersji łacińskiej nie było, np. 'gdy', lub też pomijając niektóre, np. spójnik 'i'. Miał także wgląd w PAn, ponieważ ewidentnie czerpał również z jej tekstów, tłumacząc np. imperfectum interrogabat polską formą niedokonaną „pytał”. Jednak sens pytania Jezusa próbował

${ }^{24}$ Gwiazdka (*) sygnalizuje, że słowo, przy którym ten symbol stoi, występuje w podanych tekstach, ale Wujek je pomija. Por. J. Wujek, op. cit., s. LXVIII-LXIX. Oznaczenia literowe zostały wyjaśnione w wykazie skrótów.

${ }^{25}$ Małe litery wskazują odnośniki do miejsc paralelnych w Biblii. 
oddać za pomocą konstrukcji w języku polskim, która byłaby najbliższa łacińskiej składni ACI. W podobnej postaci pojawia się ona także $\mathrm{w}$ innych polskich wersjach. W tłumaczeniu tego pytania poszedł za WL, pomijającą zaimek ' $m e$ ', dając w tym miejscu ten sam przypis co WL. W notach marginalnych wymienił manuskrypty łacińskie, greckie i syryjskie podobnie jak WL.

Werset 14 :

NTW 1593: A oni rzekli: Jedni Janem Krzcicielem, a drudzy Eliaszem, inszy też Jeremiaszem, abo jednym z proroków.

A oni rzekli.) Gdy P. Chrystus pytał uczniów swoich o ludzkim o sobie mniemaniu, tedy mu wszyścy Apostołowie odpowiedzieli. Ale gdy ich zapytał, coby też sami o nim rozumieli, tedy Piotr, jako książę i głowa wszytkich Apostołów, sam za wszytkie odpowiedział. [Chrysostomus Homil: 55. in Matthaeum].

WL: At illi dixerunt: Alij Iohannem Baptistam, alij autem Eliam, alij vero Ieremiam, aut unum ex prophetis.

PAnS: $\quad$ Ipsi vero dixerunt, Sunt qui dicunt Jouchanon Baptistam, alij vero Jlijo, alij denique Ermio aut unum ex prophetis.

PAnV: At illi dixerunt, Alij Iohannem Baptistam, alij autem Eliam, alij vero Ieremiam, aut unum ex prophetis.

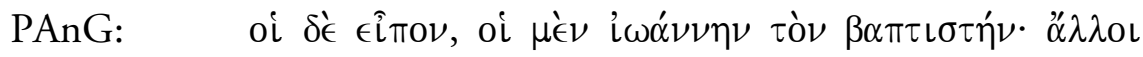

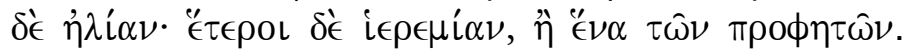

Wszystkie wersje łacińskie mają identyczny tekst. Koncepcję wyliczania Wujek zdaje się czerpać z PAnG, gdzie, podobnie, stosuje odmienne wyrażenia: ,jedni [- ], a drudzy [- ], inszy też [- ]”, nie idąc tutaj za WL i PAnV, które stosują termin 'alij'. Wujek, podobnie jak WL, nie umieścił żadnego odnośnika do wersetu 14, napisał za to komentarz oparty na źródłach patrystycznych, co jest dowodem jego kreatywności. Korzystał z innych przekładów, ale tylko pomocniczo, oraz dokonał własnej interpretacji tekstu. 
Werset 15 :

NTW 1593: Rzekł im - Jezus: A wy kim mię być powiedacie? 15. G. $^{26}$

WL: Dicit illis Iesus: Vos autem quem me esse dicitis? se non legisse, apte loquitur

PanS: $\quad$ Dixit eis, Vos autem quem me dicitis esse?

PanV: Dicit illis Iesus, Vos autem quem me esse dicitis?

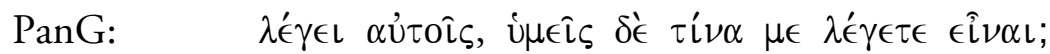

Tutaj również brakuje różnic między wersjami łacińskimi. Wujek tłumaczy dosłownie. Zaznacza rożkiem słowo, którego PAnG nie ma, a które ma łaciński tekst, tj. Jezus. Podobnie jak w wersecie 13., łacińska składnia ACI została przez niego oddana formą bezokolicznikową: „kim mię być powiedacie?”. Jednak zastosowanie formy przeszłej zaczerpnął zapewne z PAnS, która ma dixit, a nie dicit czy $\lambda^{\prime} \in \hat{\gamma} \in \mathrm{L}$, jak pozostałe teksty.

Werset 16 :

NTW 1593: A Simon Piotr odpowiedając rzekł: ${ }^{h}$ Tyś jest Chrystus Syn Boga żywego

${ }^{h} \mathrm{~J} 6,69$

Tyś jest Chrystus.) Piotr napirwszy z Boskiego objawienia poznał dwie najwyższe tajemnice wiary naszej: rozdzielność person w Bóstwie i wcielenie Syna Bożego. Hilarius na to miejsce i Athanasius sermone 4. contra Arianos, Chrysostomus, Cyrillus, Augustinus i Leo. Abowiem przystało, aby ten który miał być głowa i fundamentem kościoła Chrystusowego [wewn.: Mt 16, 18 i 19], i którego wiarę miał nieomylną uczynić [wewn.: Łk 22, 32], przodek też otrzymał w tym wyznaniu, które tak dalece przechodziło wszytko przyrodzenie i wszytek rozum ludzki (zwłaszcza patrząc

${ }^{26}$ Rożek $(\bullet)$ oznacza, że wyraz, przed którym ten symbol stoi, nie występuje w danych rękopisach, ale Wujek go uwzględnia (idąc w ten sposób za WL); cyfra oznacza liczbę tekstów. 
na człowieczeństwo i na ułomność ciała P. Chrystusowego), iż dla tej wiary i jawnego jej wyznania, nazwany jest Piotr błogosławionym, jako i Abraham dla swej wiary, i otrzymał jako i on, wielbić wielkie, a znamienite obietnice, tak sobie, jako i potomkom swoim [wewn.: Rz 4, 3]. Przetoż ś[w]. Bazyli mówi, iż Piotr, dla zacności wiary, zbudowanie Kościoła na sobie otrzymał [wewn.: Basilius libro 2. Contra Euno].

WL: $\quad$ Respondens Simon Petrus dixit, \| Tu es Christus filius Dei vivi.

J 6, 69.

PAnS: $\quad$ Respondit Schemeoun Kipho, \& ait, Tu es Meschicho filius Dei vivi.

PAnV: $\quad$ Respondens autem Simon Petrus, dixit, Tu es Christus filius Dei vivi.

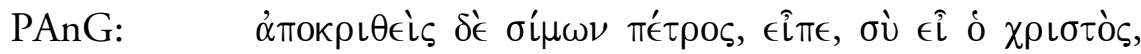

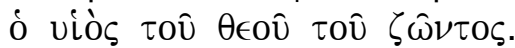

J 6, 69

Wujek odstępuje od łacińskiej składni, zmieniając miejsce podmiotu. Zapewne $A$ jest odpowiednikiem lacińskiego autem, i grec-

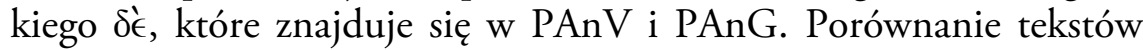
pokazuje, że Wujek nadal korzystał z WL i PAn, umieszczając na marginesie odsyłacz do J 6, 69. Ponadto w komentarzu posłużył się licznymi odwołaniami do Ojców i Doktorów Kościoła, z których dzieł czerpał, opisując już nie tylko wyznanie samego Piotra, ale wykładając prawdy dogmatyczne, takie jak odrębność Osób Boskich czy Wcielenie Syna Bożego oraz podkreślając prymat i nieomylność Piotra. Te elementy komentarza mają wyraźnie charakter polemiczny w stosunku do obozu reformacyjnego, a szczególnie w odniesieniu do antytrynitarzy.

Werset 17:

NTW 1593: A odpowiedając Jezus rzekł mu: Błogosławionyś jest Simonie ${ }^{i}$ Barjona, bo "ciało i kreẃ nie objawiła tobie, ale Ociec mój, który jest w niebiesiech. 
${ }^{i}$ Bariona znaczy synu Jony

"Ciało i krew, miasto człowieka. Hebraizm.

iJ 1,42

Btogostawionyś jest Simonie synu Jony.) Theophilaktus tak na to miejsce pisze: „Oddarował Pan Piotrowi dawszy mu tę wielką zapłatę, iż na nim Kościół swój zbudował". A Chryzostom tak wykłada te słowa [Hom: 55 in Matth]: „Jakoś ty jest własnym synem Jonaszowym, takem ja jest synem ojca mego, tejże istności z nim. [zewn.: CHRYSTUS RODZONY SYN BOŻY] Bo gdyby był Piotr nie wierzył, że Chrystus jest Synem Bożym przyrodzonym, urodzonym z Ojca, ale tylko Synem uczynionym abo sposobionym, nie trzebaćby mu było na to objawienia z nieba, aniby był zasłużył tak wielkiego błogosławieństwa”.

WL: Respondens autem Iesus, dixit ei: Beatus es Simon II Bar-Iona: quia caro \& sanguis non revelavit tibi, sed pater meus, qui in caelis est.

J 1,42

PAnS: $\quad$ Respondit Jeschua, \& dicit ei, Beatus es, Schemeoun Bere de-Javno [fili columbae,] siquidem caro $\&$ sanguis non revelavit tibi, sed pater meus qui in caelis est.

PAnV: $\quad$ Respondens autem Iesus, dixit ei, Beatus es Simon Bar-Iona: quia caro \& sanguis non revelavit tibi, sed pater meus qui in caelis est.

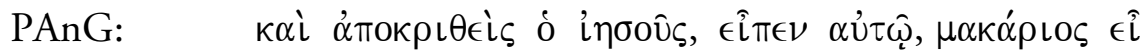

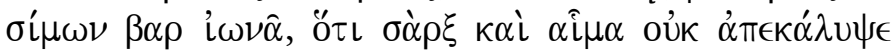

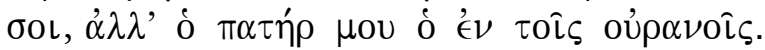

$\mathrm{J} 1,42$

Po raz kolejny umieszcza też taki sam jak WL odsyłacz - do J 1, 42. Na marginesie daje wyjaśnienie słowa „Barjona”, opatrując to komentarzem patrystycznym oraz tłumaczy hebraizm „ciało i krew". 
Werset 18 :

NTW 1593: A ja też tobie powiedam, iżeś ty jest "opoka, a na tejże opoce zbuduję Kościół mój, a brany piekielne nie zwyciężą " go.

Piotr. Petros po grecku; Cepha po żydowsku; skała abo opoka po polsku ${ }^{27}$.

" Abo jej, to jest opoki.

Tyś jest Opoka.) Z greckiego tak się właśnie ma przełożyć: Tyś jest opoka, abo skała, a na tej opoce, abo skale zbuduję mój Kościół. Przetoż się tu jawnemi fałszerzemi Pisma Świętego pokazali Czechowic i Budny, tłumacze Nowego Testamentu, Nowokrzczeńcy, gdy tak przełożył jeden: „Tyś jest opoczysty”; a drugi: „Tyś jest skalny”. Bo w greckim nie jest $\pi \in \tau \rho \alpha \imath$ lo ani $\pi \epsilon \tau \rho \eta ́ \epsilon \iota \varsigma$, ani $\pi \epsilon \epsilon \rho \iota \nu o \varsigma$, ani $\pi \epsilon \tau \rho \omega \delta \delta \eta \varsigma$, którym imieniem zowie Mateusz [wewn.: Mt 13,5] i Marek ś[w.] [wewn.: Mk 4,5] ziemie opoczystą, na której nasienie

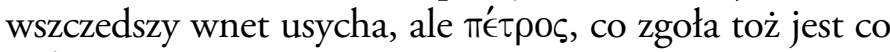
i $\pi^{\prime} \tau \rho \alpha$ po naszemu kamień, opoka, abo skała; po syryjsku, chaldejsku i po żydowsku Cepha [wewn.: J 1,42]. A gdyż to jest pewna, że Pan Chrystus do Piotra nie po łacinie, ani po grecku, ale językiem zwyczajnym, po syryjsku mówił: Tyś jest Cepha, a na tej Cephie zbuduję mój Kościół. Tedyć i to rzecz nad słońce jaśniejsza, że Pan tymi słowy nie na kim inszym jedno na Pietrze obiecał Kościół swój zbudować, uczyniwszy go pirwszym po sobie fundamentem, to jest głową Kościoła swojego. Bo co jest fundament w budowaniu, to jest głowa w ciele, król w królestwie, a gospodarz $\mathrm{w}$ domu. A przetoż zbór walny chalcedoński, na którym było 630. Ojców greckich i łacińskich, zowie Piotra opoką i fundamentem kościoła powszechnego [Acti 3]. I przed dwanaście set lat, jako Augustyn ś[w.] świadczy, toż śpiewano jawnie w kościele, w onych wierszach ś[w.] Ambrożego [In ps: cot. par. don.] [zewn.: HOC IPSA ECCLESIAE CANETE CULPAM

Ten symbol (")poprzedza wyjaśnienie trudniejszych fraz. 
DILUIT]. Prze co Hieronim ś[w.] i Augustyn ś[w.] namiastki Piotra ś[w]. i stolicę jego zową tą opoką, na której Pan Chrystus Kościół swój zbudował [Hiero: $A d$ Damasum]; iż Piotr jest opoka, nie jako prosty człowiek, abo szczególna osoba, ale jako biskup najwyższy po Chrystusie. Bo P. Chrystus, jako ś[w.] Basilius powiada, tytułów i zacności swoich rad użycza drugim [Basi: hom: de poenit.]. Kapłanem jest i kapłany czyni. Opoką jest i opoką czyni; a rzeczy swe własne daje sługom swoim. Ale jeśli przeciwnicy wszystkim doktorom chrześcijańskim wiary nie dawają, niech na koniec samym Żydom wierzą. Niech słuchają co Elias, rabin żydowski, pisze tymi słowy: „Cepha po chaldejsku znaczy skałe i mocność. Którym imieniem nazwał Jezus Nazareński ucznia swego, dając znać, iż on miał być głową i twierdzeniem wiary jego" [Elias in Thisbi].

A brany piekielne.) Stałość i trwałość wieczna tu jest obiecana, nie jedno kościołowi, ale i opoce na której Kościół jest zbudowany. Jako przypomina Orygenes sławny na tym miejscu. A tak osobnym przywilejem Piotrowi obiecano, że stolica jego nigdy nie upadnie. Jako i Augustyn ś[w.] wyznawa tymi słowy: „Liczcie biskupy, od samego Piotra na stolicy jego, a patrzajcie $\mathrm{w}$ onym rzędzie, który za kim idzie. Ten ci jest tą opoką, której nie zwyciężą brany piekielne. Której obietnice iż nie mieli inni Apostołowie, przetoż nie dziw, że ich stolice branam piekielnym ustąpić musiały" [August: In psa: cont. par. don.].

WL: $\quad$ Et ego dico tibi, quia tu es Petrus: \& super hanc petram aedificabo ecclesiam meam, $\&$ portae inferi non praevalebunt adversus eam.

PAnS: Quinetiam ego dico tibi,Tu es Kipho [petra,] \& super hanc petram aedificabo Ecclesiam meam, \& porte inferorum non praevalebunt ei. 
PAnV: $\quad$ Et ego dico tibi, Quia tu es Petrus: $\&$ super hanc petram aedificabo ecclesiam meam, $\&$ porte inferi non praevalebunt adversus eam.

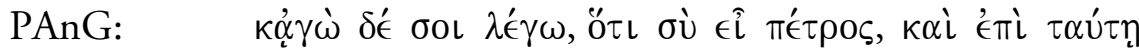

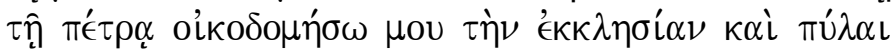

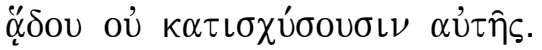

Jest to najbardziej sporny werset całej perykopy. Widać w nim usilną polemikę Wujka z Szymonem Budnym i Marcinem Czechowicem, którzy - jego zdaniem - niewłaściwie przełożyli imię Piotr. On sam tłumaczy greckie słowo $\pi \epsilon ́ \tau \rho o \varsigma$ rzeczownikowo, jako opoka (dodając na marginesie jeszcze „Piotr”), a nie przymiotnikowo, jako „opoczysty” lub „skalny” (jak czynili Czechowic i Budny). Wybór ten uzasadnia nawiązaniem do dzieł patrystycznych i do oryginalnego tekstu greckiego Biblii (tutaj bez wątpienia sięgnął do PAnS i PAnG, a nie tylko do WL). Dlatego też swoje tłumaczenie opatrzył komentarzem marginalnym, w którym podał brzmienie tego słowa po grecku, aramejsku, syryjsku, chaldejsku i hebrajsku. Wujek w komentowaniu tego wersetu wyraźnie skupia się na polemice z protestantami w kwestii prymatu Piotra. Wykorzystuje ponadto w argumentacji pracę żydowskiego gramatyka Eliasza Lewity. Nie oddał słowa

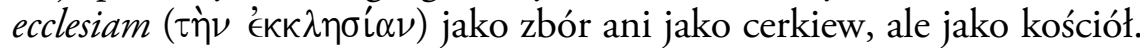
Wskazał ponadto na wyjątkowość osoby Szymona, którego imię od tej pory ma odzwierciedlać jego wyjątkową misję i moc. Dlatego też zaznaczył na marginesie, że bramy piekielne nie tylko nie zwyciężą Kościoła, ale także samego Piotra, na którym ten Kościół ma być zbudowany, podobnie jak dom na skale - ponownie polemika wokół prymatu Piotra. Warto zauważyć, że Stanisław Murzynowski i tłumacze Biblii Budnego podają w komentarzu protestancką interpretację tekstu, podkreślając oparcie Kościoła na Chrystusie oraz wskazując na wiarę Piotra, której symbolem jest tu skała.

Werset 19:

NTW 1593: ${ }^{k}$ I tobie dam klucze królestwa niebieskiego. A cokolwiek zwiążesz na ziemi, będzie związano i' w niebiesiech, a cokolwiek rozwiążesz na ziemi będzie rozwiązano $\bullet$ i' w niebiesiech.

- 9 L. G. S.

- G. 
${ }^{k} \mathrm{Mt} 18,18$

J 20, 23

I tobie dam klucze.) Przez te klucze rozumie się nawyższą zwierzchność i przełożeństwo dane Piotrowi nad wszytkim Kościołem, to jest moc rozsądzania nauk, jeśli są prawdziwe abo fałszywe; i praw stanowienia i zgromadzenia synodów i pirwszy głos na nich i potwierdzenia ich; poświęcania i stanowienia biskupów i składania ich i moc szafowania dobry kościelnymi, tak duchownymi jak i świeckimi. Abowiem taka moc i zwierzchność Pismo Ś[więte] na wielu miejscach wyraża przez klucze, jako ono tedy opisuje złożenie jednego biskupa najwyższego, a obranie inszego tymi słowy: „A dam klucz Domu Dawidowego na ramie jego i zawrze, a żaden nie otworzy, otworzy, a żaden nie zawrze" [Iz 22,22]. Także w objawieniu, jako przełożonemu miejskiemu i gospodarzowi domowemu, daniem kluczy zwierzchność nad miastem abo nad domem zlecają [Obja: 1,18 i 3,7]. A tak tymi słowy jako ś[w.] Grzegorz i ś[w.] Chryzostom piszą: „Poruczył Pan Piotrowi wszytek świat i uczynił go pasterzem i głową Kościoła wszytkiego" [Gre: epist. 32, Chry: homil: 55 in Matthaeum].

A cokolwiek zwiążesz.) W Piśmie Ś[więtym] ten zwięzuje, który rozkazuje i który karze. O rozkazaniach Pan ono mówi: „Wiążą brzemiona cięszkie i trudne ku noszeniu i kładą na ramiona ludzkie" [Mt 23, 4]. A o karaniu: „Cokolwiek zwiążecie na ziemi” [Mt 18, 18]. Ludzie lepak bywają obowiązani, tak na zachowanie rozkazania przełożonych kościelnych, jako i na podjęcie karania, jeśli ich nie chowali. A ten zaś rozwiązuje, który odpuszcza grzechy, który wyzwala od karania, który wolnymi czyni od ustaw, od ślubów, od przysiąg i od innych obowiązek podobnych. A tak gdy Pan Piotrowi mówi w obecz: Cokolwiek zwiążesz abo rozwiążesz, że daje mu moc zupełną rozkazowania, karania, zaklinania, wyzwalania, odpuszczania, rozgrzeszania i odpustów dawania, aby był 
i sędzią i przełożonym zgoła wszytkich, którzy są w Kościele.

WL: $\quad$ Et tibi dabo claves regni caelorum. Et quodcumque ligaveris super terram, erit ligatum $\triangleright \&$ ' in caelis, $\&$ quodcumque solveris super terram, erit solutum $\triangleright \&$ in caelis.

Mt 18, 18

J 20, 23

et 21,13

- 9 MS.

Hier. G. S.

PAnS: $\quad$ Tibi dabo claves regni caelorum; \& quidquid ligaveris in terra, erit ligatum in caelis \& quod solveris in terra, erit solutum in caelis.

PAnV: $\quad$ Et tibi dabo claves regni caelorum. Et quodcunque ligaveris super terram, erit ligatum $\&$ in cealis; \& quodcunque solveris super terram, erit solutum $\&$ in caelis.

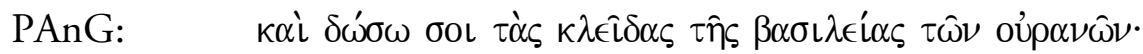

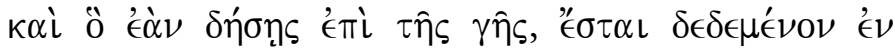

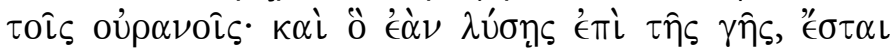

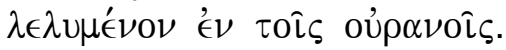

Mt 18,18

J 20, 23

Biblista z Wagrowca idzie w tłumaczeniu za tekstem WL, tłumacząc dwa razy et, którego brak w grece. U Wujka pojawiają się te same oznaczenia (rożki) i noty co w WL (z wyjątkiem odsyłacza do J 21, 13).

Werset 20:

NTW 1593: Tedy przykazał uczniom swoim aby nikomu nie powiedali że on jest Jezusem' Chrystusem.

- 6 L. N. G. S.

WL: $\quad$ Tunc preacepit discipulis suis ut nemini dicerent quia ipse esset $\bullet$ Iesus' Christus. 
- $6 \mathrm{MS}$.

G. q. s.

PAnS: $\quad$ Tunc praecepit discipulis suis, ut nemini dicerent ipsum esse Meschicho.

PAnV: $\quad$ Tunc praecepit discipulis suis ut nemini dicerent, quia ipse esset Iesus Christus.

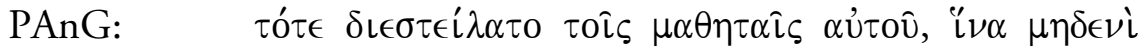

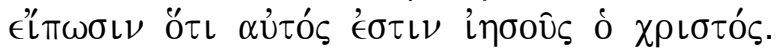

Ponownie noty krytyczno-tekstualne zapożycza Wujek z WL. Sposób przekładu jest zgodny z szykiem we wszystkich tekstach łacińskich (które tym razem nie mają składni ACI, ale szyk uzależniony od spójnika quia).

Przeprowadzone studium perykopy Mt 16, 13-20 na podstawie oryginalnych szesnastowiecznych wydań tekstów biblijnych umożliwia sformułowanie końcowych wniosków o stosowanej przez Wujka metodzie translatorskiej i komentatorskiej. Za podstawę przekładu tłumacz obrał przede wszystkim WL. Dotyczy to nie tylko tekstu, ale również odsyłaczy do miejsc paralelnych oraz not krytyczno-tekstualnych. Porównawcze studium tekstów pokazało więc, że noty nie były dziełem Wujka, ale zostały zaczerpnięte z WL. Wujek po prostu przepisywał je i nie musiał samodzielnie dokonywać krytyki tekstu. Ustalenie to było możliwe dlatego, że w powyższej analizie posłużono się oryginalnymi wydaniami Biblii z XVI w., wykorzystanymi przez Jakuba Wujka. Podkreślić wobec tego trzeba, że praca z przypadkowymi edycjami może prowadzić do niewłaściwego wyobrażenia o praktyce translatorskiej jezuity z Wągrowca. Tłumacz nie zawsze trzymał się niewolniczo tekstu łacińskiego, niekiedy odstępował od łacińskiej składni i poszukiwał poprawniejszego szyku słów w języku polskim. Jego przekład - a szczególnie komentarz - miał charakter polemiczny, wymierzony w antytrynitarzy (problem Bóstwa Chrystusa) i ogólnie ruchy reformacyjne (problem prymatu Piotra). Jeżeli zaś chodzi o wpływ WL na całą Ewangelię według św. Mateusza, to istnieje niemalże stuprocentowa zależność między nią a NTW $1593^{28}$.

${ }^{28}$ Gdy policzymy odsyłacze, to okaże się, że Wujek 579 siglów biblijnych, czyli ponad 90\% wszystkich not marginalnych, skopiował z WL. 


\section{Wykaz skrótów}

ACI - accusativus cum infinitivo

August: In psa: cont. par. don. - Augustyn, w psalmie Contra Partem Donati Basi: hom: de poenit. - Bazyli, homilia De poenitentia

BO - Biblioteka Zakładu Narodowego im. Ossolińskich we Wrocławiu

BK - Biblioteka Kapitulna we Wrocławiu

Chry: homil: 55 - Chryzostom, homilia 55

G. - (teksty) greckie

Gre: epist. 32. - Grzegorz, epistula 32

G. q. s. - (teksty) greckie, z laciny quantum satis - ile trzeba

Hiero - Hieronim

Hier. G. S. - Hieronim, (teksty) greckie, syryjskie

Hom., Homil. - Homilia

Iz - Księga Izajasza

J - Ewangelia według św. Jana

L. G. S. - (teksty) łacińskie, greckie, syryjskie

L. K. G. S. - (teksty) łacińskie (Wulgata Lowańska), królewskie (Poliglota Antwerpska) greckie, syryjskie

L. N. G. S. - (teksty) lacińskie (L.N.), greckie, syryjskie

$Ł k$ - Ewangelia według św. Łukasza

Matth - Ewangelia według św. Mateusza

Mk - Ewangelia według św. Marka

MS. - manuskrypty

MS. R. G. S. at Hier. - manuskrypty królewskie, greckie, syryjskie, u Hieronima

Mt - Ewangelia według św. Mateusza

NT - Nowy Testament

NTW 1593 - Nowy Testament w tłum. Wujka z 1593

Obja - Księga Objawienia (Apokalipsa św. Jana)

PAn - Poliglota Antwerpska

PAnG - Poliglota Antwerpska (tekst grecki)

PAnS - Poliglota Antwerpska (tekst syryjski)

PAnV - Poliglota Antwerpska (tekst łaciński)

ST - Stary Testament

wewn. - margines wewnętrzny

WL - Wulgata Lowańska

zewn. - margines zewnętrzny 


\section{Bibliografia}

Biblia Sacra Hebraice, Chaldaice, Graece et Latine. Philippi II Reg. Cathol. Pietate Et Studio Ad Sacrosanctae Ecclesiae Usum, t. 1-8, Antverpiae 1569$-1572$

Biblia sacra: Quid in hac ediotione a Theologis Louaniensibus praesitum sit, paolo post indicatur, Antverpiae, K. Plantinus 1574

Biblia to iest Ksiegi Starego y Nowego Testamentu wedtug Eacińskiego przektadu starego, $w$ kośćiele powszechnym przyiętego, na Polski ięzyk z nowu z pilnościa przetożone. Z doktadaniem textu Żydowskiego y Greckiego, y z wyktadem Katholickim, trudnieyszych mieysc, do obrony Wiary świętej i powszechney przeciw kacerztwom tych czasów należacych. Przez D. Jakuba Wuyka z Wagrowca Theologa Societatis Iesu. W Krakowie, Roku Pańskiego M.D.XCIX, red. I. Kwilecka, H. Rothe, Padeborn-München-Wien 2010

D. Bieńkowska, Jak Jakub Wujek Pismo Święte na język polski przektadat (O warsztacie ttumacza i technice przez niego stosowanej), „Bobolanum”, IX, 1998

B. Bieńkowska, Rola glos marginalnych w przektadzie Biblii J. Wujka, „Acta Universitatis Lodziensis. Folia Linguistica”, XXIII, 1990

B. Bieńkowska, Styl jezykowy przektadu Nowego Testamentu Jakuba Wujka (na materiale czterech Ewangelii), Łódź 1992

J. Czerniatowicz, Niektóre problemy naukowe grecystyki w pracach biblistów polskich XVI i XVII wieku. Teksty greckie a polskie przektady, Wrocław 1969

M. Kossowska, Biblia w jezyku polskim, t. 1, Poznań 1968

D. Kuźmina, Jakub Wujek (1541-1597). Pisarz, ttumacz i misjonarz, Warszawa 2004

H. Langkammer, Przektad Biblii Wujka na tle zmagań i potrzeb religijno-teologicznych ówczesnego Kościoła w Polsce, „Bobolanum”, IX, 1998

L. Moszyński, Stworzenie świata (Gn 1,1-31) w przektadzie Wujka z Wulgaty (1599) i Budnego z hebrajskiego (1572), [w:] Jan Jakub Wujek. Ttumacz Biblii na jezzk polski. W czterechsetna rocznice wydania Nowego Testamentu 1593-1993. Ksiega referatów wygtoszonych na konferencji 26 kwietnia 1993, Łódź 1994

Nowy Testament Pana naszego IESVSA CHRISTVSA. Z nowu z Laćińskiego y $z$ Gręckiego na Polskie wiernie a szczyrze przetożony: y Argumentami abo Summariuszami każdych Kśiag / y Rozdźiatow / y Annotacyami po brzegach obiaśniony. Przydane sa Nauki y Przestrogi mato nie za każdym Rozdźiatem: Porownanie Ewangelistow SS. Dźieie y drogi rozmaite Piotra y Pawta S. y Regestr rzeczy gtownieyszych na końcu. Przez D. IAKVBA WVYKA, Theologa Societatis IESV. Z dozwoleniem Starszych. Pod rozsadek Kościota S. Powszechnego Rzymskiego wszytko niech podlęże, Kraków 1593 
R. Pietkiewicz, W poszukiwaniu „szczyrego” Stowa Bożego. Recepcja zachodnioeuropejskiej hebraistyki w studiach chrzescijańskich w Rzeczypospolitej dobry renesansu, Wrocław 2011

S. Sawicki, Biblia Wujka w kulturze polskiej, „Studia Gnieźnieńskie”, I, 1975

E. Siatkowska, Samodzielność przektadu Nowego Testamentu przez Jakuba Wujka, Jana Blahoslava i Michata Frencla, [w:] Biblia a kultura Europy. 2000 lat chrześcijaństwa, t. 1, red. M. Kamińska, E. Małek, Łódź 1992

J. Sobczykowa, Myśl o jezyku w komentarzu biblijnym ks. Jakuba Wujka, Katowice 2001

G. Voste, La volgata al Concilio di Trento, „Biblica”, XXVII, 1946

\section{Louvain edition of the Vulgate and The New Testament in the translation of Jakub Wujek from year 1593 The study from Matthew 16:13-20}

The article is devoted to the influence of the Louvain edition of the Vulgate on the workshop of Jakub Wujek, one of the most famous 16th-century translators of the Bible. This relationship is shown based on the example of the pericope concerning the promise of the primacy of St Peter from Matthew 16:13-20. Until now, studies of the method of the Jesuit from Wagrowiec have availed themselves at random of various editions of the Vulgate (different from those used by the translator, including even modern translations), leading to erroneous conclusions about his workshop. The article comprises the exact editions on which Wujek based his work. This method enabled the discovery that the marginal notes added to the text by the translator were not compiled by him, but transcribed from the Louvain edition of the Vulgate.

Paulina Nicko-Stepień, doktorantka w Instytucie Studiów Klasycznych, Śródziemnomorskich i Orientalnych Uniwersytetu Wrocławskiego oraz Papieskiego Wydziału Teologicznego we Wrocławiu. Prowadzi badania w zakresie biblistyki, szczególnie archeologii i filologii biblijnej.

E-mail: paulina.nicko-stepien@uwr.edu.pl. 